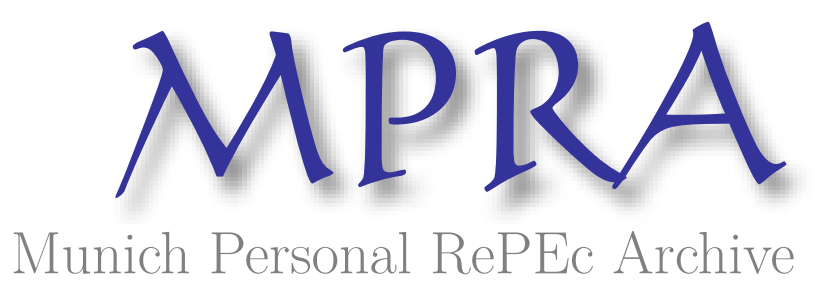

\title{
The environmental Kuznets curve within European countries and sectors: greenhouse emission, production function and technology
}

\author{
Auci, Sabrina and Trovato, Giovanni \\ University of Palermo, Department of European Studies and \\ International Integration, University of Rome Tor Vergata, \\ Department of Economics
}

30 January 2011

Online at https://mpra.ub.uni-muenchen.de/53442/ MPRA Paper No. 53442, posted 07 Feb 2014 08:09 UTC 


\title{
The Environmental Kuznets Curve within European countries and sectors: Greenhouse emission, production function and technology
}

\author{
Preliminary version
}

January 2011

\author{
Sabrina Auci \\ University of Rome Tor Vergata, Department of Centre for Economic and International Studies (CEIS).
}

\section{Giovanni Trovato}

University of Rome Tor Vergata, Department of Economics and Centre Interdepartmental for Bio-statistics and Bio-informatics (CIBB).

\begin{abstract}
Following the environmental Kuznets curve (EKC) literature and the theoretical climate change literature, we analyse the impact of per capita GDP on $\mathrm{CO}_{2}$ emissions at industrial level for several European countries. This relationship is evaluated comparing the adjusted $\mathrm{EKC}$ specification $-\mathrm{CO}_{2}$ emission conditioned by the effects of income and final energy-consumption of several energy sources - to the simultaneous equations model, considering the determinants of income. Following Dean (2002) we introduce a second equation that takes into consideration the technological progress, measured by human and physical capital, productivity and R\&D expenditure. Theoretically, it is well known that new technology and renewable energy adoptions can force the system to a more efficient economy system in term of environment and in term of quality of life. To verify if environmental policy can influence technological change, we address the effect of R\&D expenditures and R\&D intensities on output, and simultaneously we test weather the output (measured by the per capita GDP) affects or not the greenhouse gas emissions. In this simultaneous equation model, the shape of the $\mathrm{GDP}-\mathrm{CO}_{2}$ relationship appears quite sensitive to both sectors and countries. However, the analysis confirms the existence of an EKC among the European countries and sectors.
\end{abstract}

JEL numbers: Q53, Q55

Keywords: Air Pollution, Environmental Kuznets curve; Technological progress; Structural change; Environmental policy sustainable development; $\mathrm{CO} 2$ emission 


\section{Introduction}

As economy grows, environmental degradation and climate change are likely to have deleterious effects on natural and human systems, economies and infrastructure. The negative link between economic growth and environmental degradation is the reason to call for environmental policy responses and strategies at the local, regional, national and global level. The threat of climate change, potentially produced by the growing accumulation of greenhouse gases (GHG) in the atmosphere, has led to an increasing number of theoretical and empirical models for climate change policy analysis on the one hand and for the inverted U-shaped relationship between pollution and economic growth, the so-called Environmental Kuznets Curve (EKC) on the other hand. Until now, these two fields of literature have been developed separately.

The first strand of literature dealing with climate change has proposed a number of theoretical models mainly based on issues related to technological change. An understanding of the process of technological change is important for two broad reasons. First, national development and economic growth can have a different impact on the environment due to the rate and direction of technological change. New technologies may create or facilitate increased pollution, or may mitigate or replace existing polluting activities. Second, environmental policy and rules can create new constraints and incentives that affect the process of technological change. These induced effects of environmental policy on technology may have deep implications for the normative analysis of policy decisions ${ }^{1}$.

The second field of literature considers the relationship between environmental degradation and growth mainly as an empirical phenomenon. The Environmental Kuznets Curve derives its name from the work of Kuznets (1955) who has postulated a similar relationship between income inequality and economic development. In this case, however, the inverted U-shape means that environmental quality deteriorates at the beginning of the stage of development and improves when economy grows. In other words, in the first stage of industrialization, pollution grows rapidly because high priority is given to increase material output, and people are more interested in jobs and income than clean air and water (Dasgupta et al., 2002). The rapid growth inevitably results in greater use of natural resources and emission of pollutants, which in turn put more pressure on environment. People are too poor to pay for abatement, and/or disregard environmental consequences of growth. In later stage of industrialization, as income rises, people value

\footnotetext{
${ }^{1}$ For a complete survey on the relationship between technology and the environment see Jaffe et.al. (2000 and 2002) and Löschel (2002)
} 
the environment more, regulatory institutions become more effective and pollution level declines. In brief, Environmental Kuznets Curve is a statistical artefact that summarizes a few important aspects of collective human behaviour in two-dimensional space (Dinda, 2004).

The early EKC empirical models show the limit of being built on heuristic theories or ex post theoretical justifications of their findings rather than ex ante formal derivations from individual optimizing behaviour. Attempting to supply the appropriate theoretical underpinnings to the Environmental Kuznets Curve, the results of the recent theoretical literature are substantially consistent with the findings of the empirical literature. However, each model focuses on specific mechanisms from which the inverted U-shape relationship may be derived. These models underline several characteristics such as production and abatement technology on the supply-side and preferences and their evolution with income growth on the demand-side (Panayotou, 2000; Stern, 2004 and Levinson, 2001). According to the survey of Panayotou (2000), the theoretical models can be divided into four categories: (i) optimal growth models, where Tahvonen and Kuuluvainen (1994) and Selden and Song (1995) present models that extend the basic dynamic optimization of Ramsey, Cass and Koopmans to include the disutility of pollution that arises as a result of economic activity; (ii) models in which the environment (rather than pollution) is a factor of production, where Lopez (1994) and Chichilinsky (1994) consider the environment as the stock of natural capital that the economy is endowed with in the production function, (iii) endogenous growth models, where Lighthard and van der Ploeg (1994), Bovenberg and Smulders (1995, 1996), and Stokey (1998) show a production function similar to Romer's type, that is they are characterized by increasing returns to scale and spillover effects; and (iv) other macroeconomic models of growth and the environment, where Copeland and Taylor (1994), John and Pecchenino (1994), John et al. (1995) and Jones and Manuelli (2000) add additional insight to the results of the optimal growth and endogenous growth models, developing a Dimond's type overlapping generation model.

As explained by Galeotti (2003), these theoretical models are not confronted with the data, it is difficult to choose the most realistic one. For this reason, the literature on climate change and environmental policy can help showing the optimal growth model as the predominant. Models in this area are typically simulated over a number of future periods based on actual data for a specific year and of parameters that are calibrated to existing estimates. Climate models usually deal with greenhouse gasses, such as the global pollutant: carbon dioxide. However, even if this literature has proposed a number of theoretical models useful to policy-makers to choose the most appropriated incentive to promote the technology change, no studies have explicitly considered the relation between environment and development from the EKC perspective. The Galeotti (2003)'s analysis 
has highlighted the role of endogenous technical change, using the RICE optimal growth model designed for climate change policy analysis (Narwhals and Yang, 1996), and has carried out a few simulation exercises with the purpose of characterizing the relationship between economic growth and $\mathrm{CO}_{2}$ emissions. In particular, the author has assessed the decomposition of the environment-growth relationship by Grossman (1995) into three effects scale, composition, and technology components. The result does not produce an inverted-U relationship between per capita $\mathrm{CO}_{2}$ pollution and income, but "green" technical change has a positive effect in the sense that changes in the emission intensity over time induce a reduction in the positive slope of the environment-income relationship, but not enough to turn it negative.

Based on the interrelation between these two fields of literature but differently from Galeotti (2003)'s analysis, our original contribution to the literature is to verify within the EKC framework the indirect influence of technological change on emissions through the production function. In particular, following Auci and Becchetti (2006)' analysis, we test empirically the "adjusted EKC hypothesis" in which the impact of per capita GDP on $\mathrm{CO}_{2}$ emissions is evaluated conditionally to the effects of the energy-supply infrastructure. Moreover, we consider the inputs of per capita GDP such as labour, human capital and physical capital, as well as what generates technology changes. In other words, to take into consideration invention and innovation as first steps for improving economic activity, we focus on firms and public $R \& D$ expenditure. The importance of firm $R \& D$ expenditure is confirmed by Jaffe and Palmer (1997)' analysis, in which they have examined the correlation between pollution expenditures by industry and indicators of innovation. They found that there is a significant correlation within industries over time between the rate of expenditure on pollution abatement and the level of R\&D spending. However, they did not find evidence of an effect of pollution control expenditure on overall patenting.

The remaining of the paper is organized as follows. The second section provides the background literature of the relationship of the environment with both economic growth and technological change. In the third section, we describe the empirical model used to estimate the existence of the inverted U-shape curve. The forth section describes and comments the main econometric findings, and finally, in the last section, we conclude with some policy implications.

\section{Literature review and conceptual aspects of EKC}

Many surveys, such as Borghesi (1999); Stagl (1999); Panayotou (2000); Yandle et al. (2004) and Dinda (2004), have classified the EKC literature on several factors that are 
responsible to shape the EKC. The explanation, which we are mainly interested in, regards the channels economic growth affects the quality of the environment.

In this empirical literature, the income-environment relationship specified and tested could be considered as a reduced form function that aims to capture the "net effect" of income on the environment. Income is used as an omnibus variable representing a variety of underlying influences, whose separate effects are obscured (Panayotou, 2000).

A first attempt to identify the different effects of economic development on environmental quality transmitted through the income variables is carried out by Grossman (1995), Panayotou (1997) and Islam, Vincent, and Panayotou (1999). These authors identified three distinct structural forces that affect the environment. The first two forces are the same for all the authors. In particular, they distinguish between the scale effect ${ }^{2}$ of economic activity and the composition or structure effect ${ }^{3}$ of economic activity. As regards, the third effect Panayotou (1997) and Islam, Vincent, and Panayotou (1999) consider the pure income or abatement effect, while Grossman (1995) identifies the technique effect.

As regards the third effect, Panayotou (1997) and Islam, Vincent, and Panayotou (1999) consider the effect of income on the demand and supply of pollution abatement efforts, while Grossman (1995), considering only the supply side, developed the concept of the technological progress. On the demand side, the relationship between income and environmental degradation follows an inverted-J curve. This means that, at low incomes, the demand for less environmental degradation is low, while at higher income levels, demand for environmental quality is higher. On the supply side, higher incomes make available the resources needed for increased private and public expenditures (R\&D) on pollution abatement, and induce stricter environmental regulations that internalize pollution externalities. In other words, as income increases, a wealthier country can afford to spend more on R\&D. This generally leads to the substitution of obsolete and dirty technologies with cleaner ones, which also improves the quality of the environment. Hence, the abatement effect is expected to be a monotonically decreasing function of income. In conclusion, an inverted-U relationship between environmental degradation and per capita income means the prevalence of the scale effect (negative impact) in the initial

\footnotetext{
${ }^{2}$ The scale effect means that the larger the scale of economic activity per unit of area the higher the level of pollution, all else equal. In other words, an increasing output needs more inputs and thus more natural resources are used up in the production process. As a consequence of output growth, the economic activity produces more wastes and pollution, which are the main sources worsening the environmental quality.

${ }^{3}$ The structural change affects environmental quality by changing the composition of economic activity from higher pollution intensity sector to lower ones. In fact, as Panayotou (1993) has pointed out, environmental degradation tends to increase as the structure of the economy changes from rural to urban, from agricultural to industrial, but it starts falling with the second structural change from energy-intensive heavy industry to services and technology-intensive industry.
} 
stages of growth, while as an economy grows this negative effect is outweighed by the positive impact of the composition and technique effects that tend to lower the emission level.

The recent analysis of Bouvier (2004), using data from European and North American countries from the period 1980-1986, indicates that the scale effect outweighs the composition and technology effects in the cases of carbon dioxide and volatile organic compounds, while the opposite is true in the cases of carbon monoxide and sulphur dioxide. Bruvoll and Medin (2003), using a decomposition analysis, have isolated eight different factors. Among these factors are economic growth, changes in the relative size of production sectors and changes in the use of energy. The potential degradation of the environment has been counteracted by, first of all, more efficient use of energy and abatement technologies. In addition, the substitution of cleaner technology for polluting energy types and other technological progressions and political actions has reduced the growth in emissions. The results indicate that policymakers may reduce emissions considerably through creating incentives for lower energy use and substitutions of environmental friendly for environmental damaging energy types, in addition to support environmental friendly research or to conduct direct emission reducing actions, such as abatement requirements or banning of environmental damaging products.

In general, developed countries show a more stable production structure with respect to the rapidly industrializing and developing countries. For this reason, structural change is less important than technological innovation, represented by the change in emission intensity across sectors, as explained by declining SO2 emissions in the Netherlands and West Germany of de Bruyn (1997)'s analysis. The author's result is not surprising since both these countries are developed economies having undergone most of these structural changes prior to 1980 . The changes in production structure in developed economics are not accompanied by equivalent changes in composition of production. In contrast, there has been considerable technical change during the period especially in the form of policyinduced of abatement technology and more modest progress in terms of fuel substitution and use of more energy efficient technologies. This finding underlines the importance of environmental policies in bringing about environmental improvement at least in developed countries.

The technological progress leads to greater efficiency in the use of energy and materials. As income grows, people can adopt better and efficient technology that provide cleaner environment. For this reason, people prefer to spend more money in R\&D. In particular, Komen et al. (1997) have found that the income elasticity of public R\&D funding for environmental protection is positive. This is confirmed by the analysis of Magnani (2000) where public expenditure on R\&D for environmental protection increases in the case of 19 OECD countries over the period 1980-1994. Thus, public investment in R\&D represents a 
key role for environmental improvements in reducing environmental degradation (Dinda, 2004). In other words, expenditure for environmental R\&D is used as proxy for the intensity of public engagement in environmental problems.

However, another important aspect is not considered in the literature: the direction of causality (Borghesi, 1999). In other words, nobody has considered whether growth affects the environment or the other way around. Reduced-form relationships "reflect correlation rather than a causal mechanism" (Cole et al. 1997, p.401). Stern et al. (1994) and Pearson (1994) have underlined the possibility that environmental quality could have a feedback effect on income growth. As a matter of fact, the environment is a major factor of production in many underdeveloped countries that heavily rely on natural resources as a source of output. Therefore, environmental degradation in these countries is likely to reduce their capacity to produce and hence to grow. Hence, a simultaneous-equation model may be more appropriate for understanding the environment-income relationship (Borghesi, 1999).

A simultaneous-equation model is a system of equations in which environmental quality and income are both endogenous variables. The first attempt has been carried out by Dean in an early study of 1996 and then published in 2002 in Canadian Journal of Economics. Dean applies this method to investigate the impact of trade liberalization on environmental quality in developing countries. To demonstrate that trade liberalization does not harm the environment in the developing countries, the author has used a simultaneous equations system which incorporates multiple effects of trade liberalization on the environment. Estimation using pooled provincial data on Chinese water pollution, suggests that freer trade aggravates environmental damage via the terms of trade, but mitigates it via income growth. Simulations suggest that the net effect in China was beneficial.

Thus using a simultaneous model, we will show the multiple effects of technological progress on the environment. In particular, bringing together the EKC literature with the technological change, we first recall the debate on how technological progress should be considered within the environmental literature. As described in the survey of Löschel (2002), numerous economic modelling studies have taken technical progress as a noneconomic and exogenous variable. Johansson and Kriström (2007) show how the EKC can be viewed as a particular form of equilibrium relationship, where technology and preference parameters determine the shape of the curve. They show how its slope has an intuitive connection to a kind of substitution and income effect. Their model focuses on exogenous technological change in line with Brock and Taylor (2004)'s analysis that the EKC is closely linked to the long-run growth process.

However, there is overwhelming evidence that technological change is not an exogenous variable but to an important degree endogenous, induced by needs and pressures. Hence, 
some environment economy models treat technological change as endogenous, responding to socio-economic variables. Three main elements in models of technological innovation are: (i) corporate investment in research and development, (ii) spillovers from $R \& D$, and (iii) technology learning, especially learning-by-doing. The incorporation of induced technological change in different types of environmental-economic models tends to reduce the costs of environmental policy, accelerates abatement and may lead to positive spillover and negative leakage.

An attempt to consider technological change as endogenous is performed by Lutz et al. (2005). Their study starts from the observation that innovation and technical progress are only portrayed superficially in the predominant environmental economic top-down models and that bottom-up models neglect macroeconomic interdependencies between the modeled sector and the general economy. Thus, the authors have integrated the two approaches and have demonstrated how technological progress can be portrayed as process-related and policy-induced in the crude steel production in Germany. Results show that policy-induced technological change is-besides a switch in production processes - the major source of $\mathrm{CO} 2$ reduction for the steel sector. For market-based $\mathrm{CO} 2$ reduction policy, their findings confirm those of Ruth and Amato (2002) for the US iron and steel industry: higher costs of $\mathrm{CO} 2$ emissions reduce emissions mainly via shifts in the technology process and fuel mix. However, other driving forces for emission reduction such as a decrease in production and technological progress also play an important role. Moreover, the capital structure of industries is a very important feature of evaluating climate change policies. As this structure differs between countries and industries, there is no general rule for the best climate change policy.

Another recent attempt is that of Dinda (2005). In his analysis, he has explained the EKC in the framework of endogenous growth model. Considering a closed economy, one part of capital is used for commodity production, which generates pollution that degrades existing environment, and the remaining part is used for abating pollution (i.e., upgrading environment). Sufficient abatement activity improves environmental quality. The ratio of allocation of capital between two sectors (production and abatement) is fixed along the optimal path, but it varies along the non-optimal path that exists in the off-steady state. In the economy, allocation of capital for abatement activity varies over time. Thus, a change from insufficient to sufficient allocation of capital (i.e., investment) for abatement activity is the basis for an inverted U-shaped relationship between environmental quality and economic growth. Hartman and Kwon (2005) have developed an endogenous growth model with pollution and both human and physical capital. Human capital is produced cleanly while physical capital can be used for pollution control. In the long run it is optimal for human capital to grow more rapidly than physical capital, output, and consumption, while pollution declines for realistic parameter values. 
Having in mind all these theoretical analysis, in the next sections we estimate the link of technology progress with pollution emission indirectly through the national income, using a simultaneous equation model.

\section{Model specification}

Following Auci and Becchetti (2006)' model specification, we can distinguish between the standard unadjusted EKC and the adjusted EKC. Differently from the previous analysis, we consider the determinants of growth that indirectly could influence the level of per capita $\mathrm{CO}_{2}$.

As underlined above, the EKC literature have hypothesized that the relationship between economic growth and environmental quality is not monotonic and may change sign from positive to negative when a country reaches a certain level of income. The same phenomenon may be drawn on the supply side by changes in input and output mix when the latter are correlated with domestic per capita income. This implies an inverted-U shape relationship between environmental degradation and income.

For this reason, the EKC curve could be represented by a polynomial approximation in logarithmic terms:

$$
\ln (E / \text { pop })_{i t}=\alpha_{i}+\beta_{1} \ln (y / \text { pop })_{i t}+\beta_{2}[\ln (y / \text { pop })]_{i t}^{2}+\varepsilon_{i t}
$$

where $E$ stands for pollution emissions, pop represents total population and GDP is gross domestic production. The specification is usually estimated on panel data, with $i$ and $t$ indicating, respectively, countries (or regions) and years and with $\alpha_{i}$ intercept measuring country (region) specific time invariant effects.

From this specification the turning point income at which per capita emissions are at their maximum level is easily derived as:

$$
G D P_{\max }=\exp \left(-\beta_{1} /\left(2 \beta_{2}\right)\right)
$$

where $\beta_{1}$ and $\beta_{2}$ are the parameters of levels and square of per capita GDP in equation (1).

However, this simple specification does not consider the three effects: scale, composition and abatement effect or technique effect. For this reason, we estimate the adjusted EKC, which takes into consideration all the effects. So the first step of our analysis is to estimate the following equation that in logarithm term is: 
$\ln \left(C O_{2 i t}\right)=\alpha_{i}+\beta_{1} \ln (y / \text { pop })_{i t}+\beta_{2}[\ln (y / \text { pop })]_{i t}^{2}+\beta_{3} \ln (\text { oil })_{i t}+\beta_{4} \ln (\text { gas })_{i t}+\beta_{5} \ln (\text { res })_{i t}+\varepsilon_{i t}$

where, $\alpha_{i}$ represents the country $(i)$ intercept in time $t$; the $\beta_{1 . \ldots 2 . k}$ are the coefficients of the variables included. In particular, as dependent variable is considered the logarithm of per capita emission of carbon dioxide $\mathrm{CO}_{2 i t}$, stemming from the burning of fossil fuels; as independent variables we consider first of all the logarithm of the ratio between gross domestic product $(y)$ and popolation (per capita GDP) $\left(\frac{y}{p o p}\right)$ and its square value $\left(\frac{y}{p o p}\right)^{2}$ as described by the EKC hypothesis. Then, we consider the scale effect using as proxy variables $\ln ($ oil $) \ln ($ gas $)$ and $\ln ($ res $)$. These variables represent, respectively, the logarithm of the share of oil, gas and renewable and wastes (such as solar heat, biomass, geothermal, wastes) used to generate energy for final consumption of electricity. Differently from Auci and Becchetti (2006), we do not need to consider explicitly the output mix effect because our data are collected at sector level as we will explain in detail in the next section.

Having in mind the literature regarding the technological progress, we do not consider sufficient to estimate these effects but we affirm that the determinants of growth and in particular the $R \& D$ spending are the main indirect aspect that can contribute to reduce pollution. For this reason, as an econometric model we use a two simultaneous equations model, estimated by the generalized least square method applied to panel data. The first equation presents the relationship between $\mathrm{CO}_{2}$ and per capita GDP as described in the equation (3). The scale and composition effect is taken into consideration through the energy final consumption from several energy sources.

The second equation represents per capita GDP as an endogenous variable. In fact, this relationship can be considered as a production function with several factors such as physical and human capital, labour productivity and net installed capacity of thermal and hydro power stations, of geothermal plants, of wind turbines, of photovoltaic systems and finally of municipal solid wastes

In logarithm term, the equation estimated is:

$\left(\frac{y}{\text { pop }}\right)_{i t}=\gamma_{i}+\delta_{1} \ln (s s)_{i t}+\delta_{2} \ln (s t)_{i t}+\delta_{3} \ln \left(\frac{V A}{h l h s}\right)_{i t}+\delta_{4} \ln \left(\frac{V A}{h l l s}\right)_{i t}+\delta_{5} \ln \left(\frac{V A}{\text { tot imp }}\right)_{i t}+\delta_{6} \ln (I p r)_{i t}+$
$+\delta_{7} \ln (I p l)_{i t}+\delta_{8} \ln (\varepsilon)_{i t}+\delta_{9} \ln (\omega)_{i t}+\delta_{10} \ln (\chi)_{i t}+\delta_{11} \ln (\eta)_{i t}+\delta_{12} \ln (\tau)_{i t}+\delta_{13} \ln (\ell)_{i t}+\varepsilon_{i t}$

where $\gamma_{i}$ represents the country $(i)$ intercept in time $t$ and the $\delta_{1,2 \ldots k}$ are the coefficients of the variables included. As dependent variable is considered per capita GDP $\left(\frac{y}{p o p}\right)$ while 
as independent variables are considered 13 different factors. The logarithm of secondary school $(\ln (\mathrm{ss}))$ and of university represent the different levels of employees' education; $\left(\frac{V A}{h l h s}\right)$ is the logarithm of the ratio between the sector value added and sector hours worked by high-skilled person engaged, $\left(\frac{V A}{h l l s}\right)$ is the logarithm of the ratio between the sector value added and sector hours worked by low-skilled person engaged; $\left(\frac{V A}{\text { tot imp }}\right)$ represents the contribution of all person engaged to the sector value added. The variables $\ln (I p r)$ and $\ln (I p l)$ represent the R\&D expenditure by private and public sectors respectively. Finally, the last six variables define the logarithm of net installed capacity of thermal $\ln (\varepsilon)_{i t}$, and hydro $\ln (\omega)_{i t}$ power stations, of geothermal plants $\ln (\chi)_{i t}$, of wind turbines $\ln (\eta)_{i t}$, of photovoltaic systems $\ln (\tau)_{i t}$ and finally of municipal solid wastes $\ln (\ell)_{i t}$.

\section{Descriptive evidence and empirical results}

For our empirical analysis, we have built our sector level panel data, considering 25 European countries such as Austria, Belgium, Cyprus, Denmark, Estonia, Finland, France, Germany, Greece, Ireland, Italy, Latvia, Lithuania, Luxembourg, Malta, the Netherlands, Poland, Portugal, United Kingdom, Czech Republic, Slovak Republic, Slovenia, Spain, Sweden and finally Hungary. Data are collected yearly from 1997 to 2005. As regard the sectors, we take into consideration only five sectors such as "Air transport"; "Electricity, gas\&water supply"; "Land transport, transport via pipelines"; "Manufacturing" and finally "Transport, storage \& communications". The main characteristic of these sectors is that their contribution to pollution is the most important. Data are drawn mainly by the European statistical office (EUROSTAT). However, the variables of labour productivity are drawn by the EU-KLEMS dataset, a research project financed by the European Commission, to overcome some bottlenecks due to the lack of available statistics on the composition of labour and capital at the industry level for a sufficient number of European countries. The Table 1 reports the descriptive statistics of all variables included into the estimation model.

The results of our estimation model, as reported by Table 2, confirm both the EKC literature and the importance of technological progress to reduce pollution. In other words, it exists the inverted U-shape relationship between $\mathrm{CO}_{2}$ and per capita GDP if the determinants of income are considered. In particular, in the second and in the third columns the coefficients and the p-values of the adjusted EKC are reported. It is plainly noted that coefficients of income and square income are not significant even if signs are 
correct. This means that there is a clear mispecification of the model at the sector level. For this reason, in order to overcome the endogeneity problem and the subsequently causality problem, following Dean (2002) we introduce a second equation that takes into consideration the technological progress, measured by human and physical capital, productivity and R\&D expenditure. In fact, as the economy grows the emissions increases until it is reached a turning point after that the technology effect measured by investment in $R \& D$ dominates and the environmental damage decreases dramatically.

In Table 2, we can note that the expected coefficient signs are confirmed by the simultaneous two equations model. In particular, the representation of the emissionincome relationship shows the desired sign for the existence of an EKC: the coefficient of per capita GDP is positive and significant and the coefficient of per capita GDP square is negative and strongly significant. By looking to the share of final consumption of energy from oil, gas and renewable and wastes, only the sign of oil is positive and significant, as shown in the Auci and Becchetti (2006)' analysis, while the signs of gas and renewable and wastes are negative and significant.

As regards the influence of structural national or sectoral factors, considering per capita GDP as an endogenous variable, the signs obtained are as we expect. In particular, the low level of education shows a negative and significant sign while the high level of education has a positive one. A high-skilled human capital is an important factor to influence economic growth, as described by the economic growth literature. Technological progress induced by private $R \& D$ expenditure has a positive sign while the sign of public $R \& D$ expenditure shows a puzzle result. Finally, as proxies of production structure, we consider the net installed capacity of energy production. The only two variables, showing not significant coefficients, regard the net installed capacity of thermal power stations and of wind turbines. The coefficients of the other net installed capacities are significant and with positive sign.

\section{Conclusions}

Considering two fields of the environmental literature the climate change theoretical models and the empirical relationship between environmental degradation and income, our original contribution to the literature has been to verify within the EKC framework the indirect influence of technological change through the production function. In particular, following Auci and Becchetti (2006)' analysis, we have estimated a simultaneous two equations model. The first represents the "adjusted EKC hypothesis" in which the impact of per capita GDP on $\mathrm{CO}_{2}$ emissions is evaluated conditionally to the effects of the energy-supply infrastructure, while the second represents the main characteristics of per 
capita GDP such as labour, human capital and physical capital, as well as firms and public R\&D expenditure.

Our findings confirm that there exists an inverted U-shaped relationship between income and emission of carbon dioxide and in particular verified the superiority of the adjusted EKC specification. Moreover, our results emphasize the importance of the determinants of growth such as human capital and private $R \& D$ expenditure. In particular, it is highlighted the positive relation with per capita GDP of both high-skilled employees with respect to low-skilled employees and private expenditure in R\&D. We are therefore led to conclude that, the inverted U-shape relationship between carbon dioxide and per capita GDP is influenced by the characteristics that explain the endogenous growth model. 


\section{REFERENCES}

Archibugi D. and Coco A., (2004), "A New Indicator of Technological Capabilities for Developed and Developing Countries (ArCo)", World Development, 32(4), 629-654

Auci S. and Becchetti L., (2006) "The Instability of the Adjusted and Unadjusted Environmental Kuznets Curves", Ecological Economics, 60, 282-298

Baldwin R., (1995), "Does sustainability require growth?”, in Goldin I. and Winters, L.A. (Eds.), The Economics of Sustainable Development, Cambridge University Press, Cambridge, 19-46.

Borghesi S., (1999), "The Environmental Kuznets Curve: A Survey of the Literature", Working Paper, 85.1999, Fondazione ENI Enrico Mattei, Milano

Bouvier R.A., (2004), “Air Pollution and Per Capita Income: A Disaggregation of the Effects of Scale, Sectoral Composition, and Technological Change" Political Economy Research Institute Working Paper Series, 84

Bovenberg A.L. and Smulders S.A., (1995), "Environmental Quality and Pollutionaugmenting Technological Change in a Two-sector Endogenous Growth Model", Journal of Public Economics, 57, 369-391

Bovenberg A.L. and Smulders S.A., (1996), "Transitional Impacts of Environmental Policy in an Endogenous Growth Model", International Economic Review, 37, 861-893

Brock W. and Taylor M., (2004), “The green solow model”, NBER Technical Working Paper, 10557

Bruvoll A. and Medin H., (2003), "Factors Behind the Environmental Kuznets Curve A Decomposition of the Changes in Air Pollution", Environmental and Resource Economics, 24, 27-48

Chichilinsky G., (1994), "North-South Trade and the Global Environment", American Economic Review, 851-874

Cole M.A., Rayner A.J. and Bates J.M., (1997), "The environmental Kuznets curve: an empirical analysis", Environment and Development Economics, 2, 401-416

Copeland B.R. and Taylor M., (2004), “Trade, Growth, and the Environment”, Journal of Economic Literature, 42, 7-71

Costantini V. and Martini C., (2006), "A Modified Environmental Kuznets Curve for Sustainable Development Assessment Using Panel Data", Fondazione ENI Enrico Mattei, Nota di Lavoro, 148.2006

Cropper M. and Griffiths C., (1994), "The interaction of population growth and environmental quality", American Economic Review, 84, 250-254.

Dasgupta S., Laplante B., Wang H. and Wheeler D., (2002), "Confronting the Environmental Kuznets Curve", Journal of Economic Perspectives, 16(1), 147-168 
de Bruyn S.M., (1997) "Explaining the Environmental Kuznets Curve: Structural Change and International Agreements in Reducing Sulfur Emissions", Environment and Development Economics, 2(4), 485-503

de Bruyn S.M., van den Bergh J.C.J.M. and Opschoor J.B., (1998), "Economic growth and emissions: reconsidering the empirical basis of Environmental Kuznets Curves", Ecological Economics, 25, 161-175.

Dean J.M., (1996), "Testing the impact of trade liberalization of the environment", Johns Hopkins University, Washington D.C., mimeo.

Dean, J.M., (2002), "Does trade liberalization harm the environment? A new test", Canadian Journal of Economics, 35(4), 819-842

Dinda S., (2004), "Environmental Kuznets Curve Hypothesis: A Survey”, Ecological Economics, 49, 431- 455

Dinda S., (2005) "A Theoretical Basis for the Environmental Kuznets Curve", Ecological Economics 53, 403- 413

Friedl B. and Getzner M., (2003), "Determinants of CO2 emissions in a small open economy”, Ecological Economics 45(1), 133- 148

Galeotti M., (2003), "Environment and Economic Growth: Is Technical Change the Key to Decoupling?” Fondazione ENI Enrico Mattei, Nota di Lavoro 90.2003

Grossman G.M. and Krueger A.B., (1994), "Environmental impacts of a North American Free Trade Agreement", in Garber, P. (Ed.), The U.S.-Mexico Free Trade Agreement, MIT Press, Cambridge, MA

Grossman G.M. and Krueger A.B., (1995), "Economic Growth and the Environment", The Quarterly Journal of Economics, 110(2), 353-77

Grossman, G. (1995), "Pollution and Growth", in I.Goldin and L.A.Winters (eds.), The Economics of Sustainable Development, Paris: OECD, 19-46.

Hartman R. and Kwon O-S., (2005), "Sustainable growth and the environmental Kuznets curve", Journal of Economic Dynamics \& Control 29, 1701-1736

Hettige H., Lucas R.E.B. and Wheeler D., (1992), "The toxic intensity of industrial production: global patterns, trends and trade policy", American Economic Review, 82, 478-481

Hill R.J. and Magnani E., (2002), "An Exploration of the Conceptual and Empirical Basis of the Environmental Kuznets Curve", Australian Economic Papers, 41(2), 239-54

Islam N., Vincent J., and Panayotou T., (1999), "Unveiling the Income-Environment Relationship: an Exploration into the Determinants of Environmental Quality", Working Paper, Department of Economics and Harvard Institute for International Development

Jaffe A.B. and Palmer K., (1997), "Environmental Regulation and Innovation: A Panel Data Study", Review of Economics and Statistics 79:610-619 
Jaffe A.B., Newell R.G. and Stavins R.N., (2000), "Technological Change and the Environment", NBER Working Paper, 7970

Jaffe A.B., Newell R.G. and Stavins R.N., (2002), "Environmental Policy and Technological Change", Environmental and Resource Economics 22, 41-69

Johansson P.O. and Kriström B., (2007) "On a Clear Day You Might See an Environmental Kuznets Curve”, Environmental Resource Economics 37, 77-90

John A. and Pecchenino R., (1994), "An Overlapping Generations Model of Growth and the Environment”, Economic Journal, 104, 1393-1410

John A., Pecchenino R., Schimmelpfennig D., and Schreft S., (1995), "Short-lived Agents and the Long-lived Environment", Journal of Public Economics, 58, 127-141

Johnstone N., Hascic I. and Popp D., (2008), "Renewable Energy Policies And Technological Innovation: Evidence Based On Patent Counts", NBER Working Paper, 13760

Jones L.E. and Manuelli R.E., (2001), "Endogenous Policy Choice: The Case of Pollution and Growth", Review of Economic Dynamics, 4, 369-405

Kaufmann R.K., Davidsdottir B., Garnham S. and Pauly P., (1998), "The determinants of atmospheric SO2 concentrations: reconsidering the environmental Kuznets curve", Ecological Economics, 25, 209-220

Komen R., Gerking S. and Folmer H., (1997), "Income and environmental R\&D: empirical evidence from OECD countries", Environment and Development Economics $2,505-515$

Kuznets P. and Simon P., (1955), "Economic growth and income inequality", American Economic Review, 45, 1- 28

Lighart J.E. and Van der Ploeg F., (1994) "Pollutionon, the Cost of Public Funds and Endogenous Growth", Economic Letters, 339-349

Lopez R., (1994), “The Environment as a Factor of Production: the Effects of Economic Growth and Trade Liberalization", Journal of Environmental Economics and Management, 27, 163-184

Löschel A., (2002), "Technological Change in Economic Models of Environmental Policy: A Survey", mimeo

Lutz C., Meyer B., Nathani C. and Schleich J., (2005), "Endogenous Technological Change and Emissions: The Case of the German Steel Industry", Energy Policy 33, $1143-1154$

Magnani E., (1999), “The Environmental Kuznets Curve: development path or policy result?" Environmental Modelling and Software.

Magnani E., (2000), "The Environmental Kuznets Curve, environmental policy and income distribution", Ecological Economics, 32(3), 431-443

Nordhaus W.D. and Yang Z., (1996), "A Regional Dynamic General-Equilibrium Model of Alternative Climate-Change Strategies", American Economic Review, 4, 741-765 
Panayotou T., (1993), "Empirical Tests and Policy Analysis of Environmental Degradation at Different Stages of Economic Development", Working Paper WP238 Technology and Employment Programme, Geneva: International Labor Office.

Panayotou T., (1997), "Demystifying the environmental Kuznets curve: turning a black box into a policy tool", Environment and Development Economics 2, 465- 484

Panayotou T., (2000), "Economic Growth and the Environment", Center for International Development (CID) at Harvard University Working Paper No. 56 and Environment and Development Paper No. 4

Pasche M., (2002), "Technical Progress, Structural Change, and the Environmental Kuznets Curve", Ecological Economics, 42, 381/389

Pearson P., (1994), "Energy, externalities and environmental quality: will development cure the ills it creates?", Energy Studies Review, 6(3), 199-215

Robers J.T. and Grimes P.K., (1997), "Carbon intensity and economic development 1962 -1991: a brief exploration of the Environmental Kuznets Curve", World Development 25 (2), 191- 198

Ruth M. and Amato A., (2002), "Vintage structure dynamics and climate change policies: the case of us iron and steel", Energy Policy 30(7), 541-552.

Selden T.M. and Song D., (1994), "Environmental quality and development: is there a Kuznets curve for air pollution emissions?", Journal of Environmental Economic Management, 27, 147-162

Selden T.M. and Song D., (1995), "Neoclassical Growth, the $J$ Curve for Abatement and the Inverted $U$ Curve for Pollution", Journal of Environmental Economics and Environmental Management, 29, 162-168

Shafik N., (1994), "Economic development and environmental quality: an econometric analysis. Oxford Economic Papers, 46, 757-773

Smulders S. and Bretschger L., (2000), "Explaining Environmental Kuznets Curves: How Pollution Induces Policy and New Technologies" Center for Economic Research, 200095

Smulders S., Bretschgerz L. and Egli H., (2005), "Economic Growth and the Diffusion of Clean Technologies: Explaining Environmental Kuznets Curves", Swiss Federal Institute of Technology Zurich Working Paper 05/42

Stagl S., (1999), "Delinking Economic Growth from Environmental Degradation? A Literature Survey on the Environmental Kuznets Curve Hypothesis", Wirtschaftsuniversität Wien Working Paper Series of the Research Focus Growth and Employment in Europe: Sustainability and Competitiveness, 6

Stern D.I., (2004), “Diffusion of Emissions Abating Technology”, Rensselaer Polytechnic Institute Working Paper, 0420

Stern D.I., Common M.S. and Barbier E.B., (1994), "Economic growth and environmental degradation: a critique of the environmental Kuznets curve", Discussion Paper in Environmental Economics and Environmental Management, 9409, University of York. 
Stokey N.L., (1998), “Are There Limits to Growth?”, International Economic Review, 39, $1-31$

Suri V. and Chapman D., (1998), "Economic Growth, trade and energy: implications for the Environmental Kuznets Curve", Ecological Economics 25, 195-208

Tahvonen O. and Kuuluvainen J., (1993), "Economic Growth, Pollution and Renewable Resources", Journal of Environmental Economics and Management 24, 01-118

Torras M. and Boyce J.K., (1998), "Income, inequality and pollution: a reassessment of the Environmental Kuznets Curve", in Rothman D. and de Bruyn S. (Eds.), The Environmental Kuznets Curve, Ecol. Econ. 25, 147-160.

Yandle B., Bhattarai M. and Vijayaraghavan M., (2004), "Environmental Kuznets Curves: A Review of Findings, Methods, and Policy Implications”, PERC Research Study 02-1 
Table 1: Descriptive statistics of explanatory variables - 1997-2005

\begin{tabular}{|c|c|c|c|c|c|c|c|c|}
\hline variable & mean & se(mean) & cv & p25 & p50 & p75 & $\mathbf{N}$ & $\begin{array}{c}\text { interquartile } \\
\text { range = p75 - } \\
\text { p25 }\end{array}$ \\
\hline $\operatorname{co} 2$ & 95.9 & .886 & .304 & 73 & 99.5 & 115 & 1080 & 42 \\
\hline percapita GDP & 18427 & 357 & .649 & 7800 & 17900 & 26700 & 1125 & 18900 \\
\hline oil & 19048 & 774 & 1.36 & 2231 & 7836 & 16506 & 1125 & 14275 \\
\hline gas & 11418 & 521 & 1.47 & 633 & 4024 & 10579 & 1035 & 9946 \\
\hline res & 1908 & 72 & 1.24 & 379 & 769 & 3007 & 1080 & 2628 \\
\hline is $2 t$ & 873924 & 40755 & 1.46 & 177682 & 378767 & 788095 & 975 & 610413 \\
\hline is $56 \mathrm{t}$ & 656142 & 24725 & 1.18 & 130706 & 287001 & 646587 & 975 & 515881 \\
\hline vahs & 6105 & 612 & 1.91 & 392 & 1678 & 4609 & 363 & 4217 \\
\hline vals & 12600 & 2641 & 3.99 & 279 & 801 & 2495 & 363 & 2216 \\
\hline vaemp & 427 & 89 & 6.02 & 10.2 & 27.8 & 73.6 & 831 & 63.3 \\
\hline GERD_priv & 3793 & 271 & 1.77 & 199 & 812 & 3576 & 612 & 3376 \\
\hline GERD_gov & 866 & 58.7 & 1.68 & 77.9 & 237 & 829 & 615 & 751 \\
\hline nicther & 15615 & 610 & 1.31 & 2466 & 7375 & 19967 & 1125 & 17501 \\
\hline nichy & 5841 & 234 & 1.26 & 906 & 2360 & 8853 & 990 & 7947 \\
\hline nicgeo & 208 & 24.8 & 1.38 & 2 & 14 & 573 & 135 & 571 \\
\hline nicwi & 1019 & 91.9 & 2.64 & 22 & 125 & 553 & 855 & 531 \\
\hline nicph & 33.2 & 6.08 & 4.6 & 1 & 3 & 14 & 630 & 13 \\
\hline nicwas & 164 & 7.86 & 1.33 & 6 & 89 & 264 & 765 & 258 \\
\hline
\end{tabular}

Variable legend: co2: $\mathrm{CO}_{2}$ emissions (metric tons per capita); percapita GDP: per capita gross domestic product; oil: share of oil, used to generate energy for final consumption of electricity; gas: share of gas used to generate energy for final consumption of electricity; res: share of renewable and wastes (such as solar heat, biomass, geothermal, wastes) used to generate energy for final consumption of electricity; is $2 t$ : employees' secondary school education; is56t: employees' university education; vahs: ratio between sector value added and sector hours worked by high-skilled person engaged; vals: ratio between sector value added and sector hours worked by low-skilled person engaged; vaemp: ratio between sector value added and sector hours worked by person engaged; GERD_priv: R\&D expenditure by private sectors; GERD_gov: $R \& D$ expenditure by public sectors; nicther: net installed capacity of thermal power stations; nichy: net installed capacity of hydro power stations; nicgeo: net installed capacity of geothermal plants; nicwi: net installed capacity of wind turbines;nicph: net installed capacity of photovoltaic systems; nicwas: net installed capacity of municipal solid wastes. 
Table 2: Estimated coefficients of a simultaneous two-equation model using a generalized least square method

\begin{tabular}{|c|c|c|c|c|}
\hline \multicolumn{5}{|c|}{ Model of EKC with per capita $\mathrm{CO}_{2}$ as dependent variable } \\
\hline & Coef & $\mathbf{P}(\alpha)>\mathbf{z}$ & Coef & $\mathbf{P}(\alpha)>\mathbf{z}$ \\
\hline intercept & $6.350^{* * * *}$ & 0.000 & $-8.506^{* * *}$ & 0.00 \\
\hline percapita GDP & 0.139 & 0.297 & $2.679^{* * *}$ & 0.00 \\
\hline$(\text { percapita GDP })^{\wedge} 2$ & -0.008 & 0.255 & $-0.135^{* * *}$ & 0.00 \\
\hline oil & $0.294^{* * *}$ & 0.000 & $0.219^{* * *}$ & 0.00 \\
\hline gas & $0.036^{* * *}$ & 0.000 & $-0.131^{* * *}$ & 0.00 \\
\hline res & $0.011^{* * *}$ & 0.000 & $-0.033^{* * *}$ & 0.00 \\
\hline \multicolumn{5}{|c|}{ Model of per capita GDP as dependent variable } \\
\hline & Coef & $\mathbf{P}(\alpha)>\mathbf{z}$ & Coef & $\mathbf{P}(\alpha)>\mathbf{z}$ \\
\hline intercept & & & $9.616^{* * *}$ & 0.00 \\
\hline is $2 t$ & & & $-0.206^{* * *}$ & 0.00 \\
\hline is $56 \mathrm{t}$ & & & $0.391^{* * *}$ & 0.00 \\
\hline vahs & & & $0.078^{* * *}$ & 0.00 \\
\hline vals & & & $-0.026^{* * * *}$ & 0.005 \\
\hline vaemp & & & $0.156^{* * *}$ & 0.00 \\
\hline GERD_priv & & & $0.532^{* * *}$ & 0.00 \\
\hline GERD_gov & & & $-0.099^{* * *}$ & 0.00 \\
\hline Nicther & & & $-1.83 \mathrm{E}-07$ & 0.82 \\
\hline nichy & & & $-6.44 \mathrm{E}-06^{* * *}$ & 0.00 \\
\hline nicgeo & & & $0.0007^{* * *}$ & 0.00 \\
\hline nicwi & & & $5.65 \mathrm{E}-06$ & 0.22 \\
\hline nicph & & & $-0.001^{* * *}$ & 0.00 \\
\hline nicwas & & & $0.001^{* * *}$ & 0.00 \\
\hline Wald chi2 test & $1,039.19$ & 0.00 & 6282150 & 0.00 \\
\hline Number of obs & 960 & & 569 & \\
\hline Turning point & $5,928.343$ & & $20,378.23$ & \\
\hline
\end{tabular}

